\title{
The International Federation for Emergency Medicine report on emergency department crowding and access block: a brief summary
}

\author{
A. P. Javidan ${ }^{1,2^{*}}$ (D, K. Hansen ${ }^{3,4^{*}}$, I. Higginson ${ }^{5}$, P. Jones ${ }^{6,7}$, E. Lang ${ }^{8,9^{*}}$ on behalf of the IFEM Task Force on \\ Emergency Department Crowding and Access Block
}

\begin{abstract}
Objective: To develop comprehensive guidance that captures international impacts, causes, and solutions related to emergency department crowding and access block

Methods: Emergency physicians representing 15 countries from all IFEM regions composed the Task Force. Monthly meetings were held via video-conferencing software to achieve consensus for report content. The report was submitted and approved by the IFEM Board on June 1, 2020.

Results: A total of 14 topic dossiers, each relating to an aspect of ED crowding, were researched and completed collaboratively by members of the Task Force.

Conclusions: The IFEM report is a comprehensive document intended to be used in whole or by section to inform and address aspects of ED crowding and access block. Overall, ED crowding is a multifactorial issue requiring systems-wide solutions applied at local, regional, and national levels. Access block is the predominant contributor of ED crowding in most parts of the world.
\end{abstract}

Keywords: Crowding, Access block, Care systems, Emergency care systems, Emergency department management, Emergency department operations

Emergency department (ED) crowding and access block represent potentially the greatest threats to the core mission of emergency care across the world. The problem is pervasive, massive in scale, and amounts to a public health emergency with potentially lethal consequences [1]. At its core, crowding and access block overwhelm ED resources and prevent the delivery of timely and

\footnotetext{
* Correspondence: Arshia.javidan@mail.utoronto.ca;

Kim.hansen@health.qld.gov.au; Eddy.Lang@albertahealthservices.ca

${ }^{1}$ Faculty of Medicine, University of Toronto, Toronto, ON, Canada

${ }^{3}$ Emergency Department, Prince Charles Hospital, Chermside, QLD, Australia

${ }^{8}$ Department of Emergency Medicine, Cumming School of Medicine, University of Calgary, Calgary, AB, Canada

Full list of author information is available at the end of the article
}

effective care for patients. These are patients in need of necessary and immediate attention for the whole range of medical, trauma, and behavioral emergencies that can impact a person or community. The causes of ED crowding and access block are complex and multifactorial and can vary considerably not only between hospitals, jurisdictions, and countries, but also within the same setting during different periods of time $[1,2]$.

The International Federation of Emergency Medicine (IFEM) recognized that there was both an extreme need and a unique opportunity to provide EDs around the world with expert and evidence-based guidance. Recognizing crowding and access block were wicked problems

(C) The Author(s). 2020 Open Access This article is licensed under a Creative Commons Attribution 4.0 International License, which permits use, sharing, adaptation, distribution and reproduction in any medium or format, as long as you give appropriate credit to the original author(s) and the source, provide a link to the Creative Commons licence, and indicate if changes were made. The images or other third party material in this article are included in the article's Creative Commons licence, unless indicated otherwise in a credit line to the material. If material is not included in the article's Creative Commons licence and your intended use is not permitted by statutory regulation or exceeds the permitted use, you will need to obtain permission directly from the copyright holder. To view a copy of this licence, visit http://creativecommons.org/licenses/by/4.0/ The Creative Commons Public Domain Dedication waiver (http://creativecommons.org/publicdomain/zero/1.0/) applies to the data made available in this article, unless otherwise stated in a credit line to the data. 
(problems that are challenging to solve due to complexity, breadth, and/or contradictory elements) requiring adaptive solutions, the plan was to develop a resource that could be adapted to local circumstances. The ED Crowding and Access Block Task Force was constructed with this goal and endorsed by the IFEM Board and launched at the International Conference on Emergency Medicine conference in South Korea in 2019. Since that time, the ED Crowding and Access Block Task Force Terms of Reference were approved, and the task force has seen involvement from all IFEM regions. Over thirty emergency medicine (EM) physician experts and thought leaders, with a broad range of expertise, have been joining monthly video conferences and contributing to fourteen distinct dossiers and well-referenced synopses which constitute the basis for this report (Table 1).

This report examines the complexity of ED crowding and access block through multiple important lenses. These range from an accounting of the impacts of the problem through to tactical and strategic solutions including policy, advocacy, operational, and "on-the-floor" initiatives. One overwhelmingly common theme that emerged through task force deliberations is that the problem may be misnamed. ED crowding and access block is not an issue isolated to the emergency department, but fundamentally a health-systems issue [1, 3]. Emergency departments are well-prepared to serve as the "safety net" for a wide range of medical, traumatic, and behavioral emergencies; however, EDs cannot fulfill this mission if they are also forced to become the "safety

Table 1 Overview of breadth of dossier topics found in the IFEM ED Crowding and Access Block Task Force report

\begin{tabular}{l} 
Dossier topic \\
Background \\
Evidence base for effects of crowding \\
Financial and human costs of crowding \\
Metrics \\
International experience \\
Case studies and patient voices \\
Patient flow \\
Emergency medical services (prehospital services) offload \\
Input and demand management \\
Throughput \\
Output and boarding \\
Management \\
Leadership \\
Legal risks and regulatory violations \\
Policy \\
Advocacy \\
Early lessons from COVID-19 and disaster medicine \\
\hline
\end{tabular}

valve" for dysfunction and limited capacity within the community and the hospital. Despite this, the task force would also share the view that EDs that are not contributing to solutions for healthcare system dysfunction are also part of the problem, hence the vital importance of emergency care providers who are well-versed in system issues to infiltrate decision-making and public awareness realms at multiple levels.

As a "wicked problem" for health care systems internationally, experts and thought leaders around the world have invested a remarkable amount of resources to understand the problem and formulate solutions. This report is designed to leverage that vast international experience and serve as a comprehensive global resource for EDs facing the challenge of crowding and access block. This document is meant to be used as a toolbox with each section acting as one tool of many to diagnose and treat an unsafe and overwhelmed ED. Leaders in emergency care will be able to use these instruments to address their local circumstances both on a short-term and long-term basis. This report is also meant to be shared in portion, or in its entirety, with all of the stakeholders that can be impacted by ED crowding and access block as well as the partners necessary to mitigate and distribute risk and allow emergency care to fulfill its core mission.

The report, including the full list of authors, can be found in its entirety on the IFEM website [4].

\section{Acknowledgements}

Collaborators are outlined below:

International Federation Emergency Department Crowding and Access Block Task Force:

Arshia Javidan; Kim Hansen; lan Higginson; Peter Jones; David Petrie; John Bonning; Simon Judkins; Eric Revue; David Lewis; Brian Holroyd; Laurie Mazurik; Colin Graham; Alix Carter; Shirley Lee; Eliecer Cohen-Olivella; Pau Ho; Ramesh Maharjan; Bianca Bertuzzi; Haldun Akoglu; Jim Ducharme; Maaret Castren; Adrian Boyle; Howard Ovens; Cheng-Chung Fang; Joseph Kalanzi; Jeremiah Schuur; Venkatesh Thiruganasambandamoorthy; Taj Hassan; Gautam Bodiwala; Pauline Convocar; Katherine Henderson; Eddy Lang

\section{Authors' contributions}

All authors of this manuscript have contributed substantially to this manuscript's inception, analysis, and drafting, and fulfill the International Committee of Medical Journal Editors' criteria for authorship. The authors read and approved the final manuscript.

\section{Funding}

We have no financial relationships to disclose with regards to this manuscript. This research received no specific grant from any funding agency, commercial, or not-for-profit sectors.

\section{Availability of data and materials}

There is no dataset for this study. The full IFEM ED Crowding and Access

Block Report is available on the IFEM website and referenced in the paper.

Ethics approval and consent to participate

Not applicable

Consent for publication

Not applicable 


\section{Competing interests}

The IFEM ED crowding and access block report is referenced in the paper and is available on the IFEM website in its entirety. This article is being simultaneously published in the International Journal of Emergency Medicine (doi: https://doi.org/10.1186/s12245-020-00312-x), Canadian Journal of Emergency medicine (doi: https://doi.org/10.1007/s43678-020-00065-9), Emergency Medicine Journal (doi: https://doi.org/10.1136/emermed-2020210716), and Emergency Medicine Australasia (doi: https://doi.org/10.1111/ 1742-6723.13660)

Otherwise, the authors declare that they have no competing interests.

\section{Author details}

${ }^{1}$ Faculty of Medicine, University of Toronto, Toronto, ON, Canada. ${ }^{2}$ Institute of Health Policy, Management, and Evaluation, University of Toronto, Toronto, ON, Canada. ${ }^{3}$ Emergency Department, Prince Charles Hospital, Chermside, QLD, Australia. ${ }^{4}$ Emergency Department, St. Andrew's War Memorial Hospital, Brisbane, QLD, Australia. ${ }^{5}$ Emergency Department, Derriford Hospital, Plymouth, UK. ${ }^{6}$ Emergency Department, Auckland City Hospital, Auckland District Health Board, Auckland, New Zealand. 'Department of Surgery, University of Auckland, Auckland, New Zealand. ${ }^{8}$ Department of Emergency Medicine, Cumming School of Medicine, University of Calgary, Calgary, AB, Canada. ${ }^{9}$ Department of Emergency Medicine, Alberta Health Services,

Calgary, AB, Canada.

Received: 16 October 2020 Accepted: 26 October 2020

Published online: 14 January 2021

\section{References}

1. Morley C, Unwin M, Kinsman L. Emergency department crowding: a systematic review of causes, consequences and solutions. PLoS One. 2018; 13(8):e0203316.

2. Moskop JC, Sklar DP, Geiderman JM, et al. Emergency department crowding, part 1 - concepts, causes, and moral consequences. Ann Emerg Med. 2009;53:605-11.

3. Asplin BR, Magid DJ, Rhodes KV, et al. A conceptual model of emergency department crowding. Ann Emerg Med. 2003 Aug;42(2):173-80.

4. Javidan AP, Hansen $\mathrm{K}$, Higginson I, et al. Report from the Emergency Department Crowding and Access Block Task Force [Internet]. Melbourne: International Federation for Emergency Medicine; 2020. Available from: https://www.ffem.cc/resources/white-paper-from-the-ifem-emergencydepartment-crowding-and-access-block-task-force-june-2020/. [Cited September 25, 2020].

\section{Publisher's Note}

Springer Nature remains neutral with regard to jurisdictional claims in published maps and institutional affiliations.

Ready to submit your research? Choose BMC and benefit from:

- fast, convenient online submission

- thorough peer review by experienced researchers in your field

- rapid publication on acceptance

- support for research data, including large and complex data types

- gold Open Access which fosters wider collaboration and increased citations

- maximum visibility for your research: over $100 \mathrm{M}$ website views per year

At $\mathrm{BMC}$, research is always in progress.

Learn more biomedcentral.com/submissions 